\title{
PENGARUH SIKAP RELIGIUSITAS TERHADAP PERILAKU HIDUP BERSIH DAN SEHAT MASYARAKAT KABUPATEN REJANG LEBONG
}

\author{
Eka Yanuarti \\ Sekolah Tinggi Agama Islam Negeri (STAIN) Curup \\ ekayanuarti14@gmail.com
}

\begin{abstract}
This study aims to determine the influence of religious attitudes toward PHBS community at RejangLebong district. This research is field research, with approach of mixed methods, concurrent triangulation model. The results showed that the attitude of religiosity has a contribution of $83.80 \%$ to the community PHBS Dusun Curup. The attitude of the religiosity of society has an influence on the clean behavior of them, as the religious ritual dimension brings influence to the behavior of using clean water in everyday life. Then the dimension of religious consequences in the community in bringing influence on community behavior in combating mosquito larvae. The influence of the attitude of religiosity on the Psychic / Mental health of society is to make people obedient to the leadership who gave command that is Allah SWT. Coaching people have a high legislature in carrying out the duty that is given to them. Making people have an optimistic attitude in facing the future. Reassuring people's souls. Encouraging the community face the problems of life with a patient and steadfast heart. Educating people to be sportive and gentleman to admit their mistakes and sin. Avoiding people from doing despicable and evil. While the influence of medical health, has not brought significant influence as there are still many people who smoke, smoking habit has been evenly done by the fathers, not only fathers, but also the youth who are still in school and have not had a job.
\end{abstract}

Keywords: Attitude of Religiosity, PHBS, Society

\begin{abstract}
Abstrak
Penelitian ini bertujuan untuk mengetahui pengaruh sikap religiusitas terhadap PHBS masyarakat kabupaten Rejang Lebong. Penelitian ini adalah penelitian lapangan, dengan pendekatan metode kombinasi (mixed methods), Model concurrent triangulation. Hasil penelitian menunjukkan Sikap religiusitas memiliki pengaruh kontribusi sebesar $83,80 \%$ terhadap PHBS masyarakat dusun curup. Sikap religiusitas masyarakat memiliki pengaruh terhadap perilaku bersih masyarakat, seperti dimensi ritual beragama membawa pengaruh terhadap perilaku penggunaan air bersih dalam kehidupan sehari-hari. Kemudian dimensi konsekuensi beragama memasyarakat dalam membawa pengaruh terhadap perilaku masyarakat dalam memberantas jentik nyamuk. Pengaruh sikap religiusitas terhadap kesehatan Psikis/Mental masyarakat yaitu menjadikan masyarakat taat kepada pimpinan yang memberi komando yaitu Allah Swt. Melatih masyarakat memiliki kedislipinan yang tinggi dalam melaksanakan tugas yang dipikulkan kepadanya. Menjadikan masyarakat memiliki sikap optimis dalam menyongsong masa depan. Menentramkan jiwa masyarakat. Mendorong masyarakat
\end{abstract}

FOKUS : Jurnal Kajian Keislaman dan Kemasyarakatan vol. 3, no. 1, 2018

P3M Sekolah Tinggi Agama Islam Negeri (STAIN) Curup - Bengkulu

Available online: http://journal.staincurup.ac.id/index.php/JF

p-ISSN 2548-334X, e-ISSN 2548-3358 
22| Fokus: Jurnal Kajian Keislaman dan Kemasyarakatan, Vol.3, No. 01, Juni 2018

berani menghadapi problematika kehidupan dengan hati sabar dan tabah. Mendidik masyarakat bersikap sportif dan gentleman untuk mengakui kesalahan dan dosanya. Menghindarkan masyarakat dari berbuat keji dan munkar (jahat). Sementara pengaruh dari kesehatan medis, belum membawa pengaruh yang sigifikan seperti masih banyaknya masyarakat yang merokok, kebiasaan merokok sudah merata dilakukan oleh bapak-bapak, tidak hanya bapak-bapak, bahkan para pemuda yang masih sekolah dan belum memiliki pekerjaan juga sudah merokok.

\section{Kata kunci: Sikap Religiusitas, PHBS, Masyarakat}

\section{PENDAHULUAN}

Agama dalam kaitannya dengan kebudayaan dan praktik-praktik sosial dapat dipandang sebagai kepercayaan dan pola tingkah laku yang diusahakan oleh masyarakat. Agama digunakan untuk menangani masalah-masalah yang tidak dapat dipecahkan dengan teknologi ataupun teknik organisasi yang diketahuinya. Kematangan beragama dalam masyarakat terlihat pada kemampuan anggota masyarakat untuk memahami, menghayati serta mengaplikasikan nilai-nilai luhur agama yang dianutnya dalam kehidupan sehari-hari. Religiusitas merupakan perwujudan nilai-nilai yang terbentuk dalam pribadi seorang muslim bersumber dari ajaran agama Islam sebagai manifestasi ketundukan dan ketaatan seseorang kepada sang pencipta, Allah SWT.

Islam menaruh perhatian yang besar terhadap dunia kesehatan. Kesehatan merupakan modal utama untuk bekerja, beribadah dan melaksanakan aktivitas lainnya. Selain kesehatan, Islam juga menganjurkan berperilaku hidup bersih, sebab kebersihan pangkal kesehatan, dan kebersihan dipandang sebagai bagian dari iman. Banyak manfaat yang dapat diperoleh dengan memilki sikap religiusitas yang tinggi, sebagaimana diungkap oleh Deden Suparman, bahwa pelaksanaan ibadah shalat membawa manfaat untuk kesehatan medis dan psikis, manfaat psikis yaitu menghindarkan diri kita dari perbuatan keji dan munkar. Manfaat medis seperti dari mulai awal shalat kita diwajibkan berwudhu, ternyata kita harus bersih, dan bahkan tatacara shalat dari mulai takbir, ruku, sujud sampai salam tercermin didalamnya sebagai kegiatan fisik yang mencerminkan supaya organ kita bergerak sehingga 
Eka: Pengaruh Sikap Religiusitas Terhadap Perilaku Hidup Bersih... | 23 mengakibatkan menjadi sehat ${ }^{1}$ kemudian Lelya Hilda juga mengungkapkan pelaksanaan ibadah puasa juga memiliki manfaat untuk kesehatan fisik dan psikis. ${ }^{2}$ Kondisi tubuh yang sehat, dan keadaan psikis yang tenang dapat membawa warga masyarakat yang kuat sehingga tercipta masyarakat tertib dan aman, sebagaimana tercantum dalam firman Allah SWT dalam (Q.S.An-Nisaa':9) yang mengajak untuk mempersiapkan anak-anak yang kuat sehingga tidak ada kekhawatiran akan kesejahteraan mereka. Ayat di atas mengindikasikan perlunya sikap religiusitas dan perilaku hidup bersih dan sehat dalam menciptkan masyarakat yang kuat, aman, damai dan sejahtera.

Penerapan perilaku hidup bersih dan sehat (PHBS) pada masyarakat Indonesia masih merupakan suatu masalah. Hal ini dikarenakan kurangnya pengetahuan mengenai manfaat hidup sehat dan berbagai faktor kebiasaan awam yang dilakukan oleh generasi terdahulu, seperti buang air kecil maupun besar di sungai merupakan kejadian sehari-hari yang masih banyak dijumpai. Secara umum Program Kesehatan Provinsi Bengkulu tahun 2014 sudah cukup berhasil, hal ini terlihat dari hasil persentase rumah tangga berperilaku hidup bersih dan sehat di kabupaten Rejang Lebong, diketahui ada sebanyak 69.179 rumah tangga, sementara rumah tangga yang ber PHBS ada 44,892 atau 64,9\% . ${ }^{3}$

Observasi awal di kelurahan dusun curup, peneliti menjumpai adanya tumpukan sampah dan aliran air (selokan) diikuti beberapa sampah yang juga mengalir di atas aliran air tersebut, yang mana selokan ini masih digunakan untuk memenuhi kebutuhan air masyarakat dusun curup. Perilaku PHBS masyarakat dipertegas dengan hasil penelitian yang dilakukan oleh Husni Abdul Gani, tahun 2013 ${ }^{4}$, yaitu sebagian besar lakilaki berusia lebih dari 50 tahun, berpendidikan rendah (SD dan sederajat)

\footnotetext{
${ }^{1}$ Deden Suparman, Pembelajaran Ibadah Shalat dalam Perpektif Psikis dan Medis, Jurnal Edisi Juli 2015 Volume IX No. 2, ISSN 1979-8911, hlm. 48-70.

${ }^{2}$ Lelya Hilda , Puasa dalam Kajian Islam dan Kesehata, Jurnal Hikmah, Vol. VIII, No. 01 Januari 2014, hlm.53-62

${ }^{3}$ Dinas Kesehatan Provinsi Bengkulu. Profil Kesehatan Provinsi Bengkulu Tahun 2014. Bengkulu, 2015, hlm.124.

${ }^{4}$ Husni Abdul Gani, Perilaku Hidup Bersih dan Sehat (PHBS) pada Masyarakat Using di Kabupaten Banyuwangi. Jurnal IKESMA Volume 9 Nomor 2 September 2013. hlm. 147-158.
} 
serta berprofesi sebagai petani. Ada 37\% menggunakan jamban kurang sehat, dan 9\% menggunakan jamban buruk. $6 \%$ menggunakan air tidak bersih. 63\% tidak menggunakan tempat sampah. Hal ini disebabkan oleh kurangnya kesadaran responden akan PHBS, untuk itu perlu upaya terpadu dalam promosi PHBS.

Dari pemaparan di atas, peneliti tertarik melakukan penelitian lebih lanjut yang bertujuan mengetahui bagaimana sikap religiusitas masyarakat kelurahan dusun curup, bagaimana sikap PHBS masyarakat kelurahan dusun curup, dan bagaimana pengaruh sikap religiusitas terhadap PHBS masyarakat kelurahan Dusun Curup kabupaten Rejang Lebong.

Istilah religiusitas (religiosity) berasal dari bahasa Inggris "religion" yang berarti agama, kemudian menjadi kata sifat "religios" yang berarti agamis atau saleh". "Religi" berarti kepercayaan kepada Tuhan, kepercayaan adanya kekuatan diatas manusia. Religiusitas merupakan bagian dari karakteristik pribadi seseorang yang dengan sendiri akan menggambarkan personalitas sebagai internalisasi nilai-nilai religiusitas secara utuh yang diperoleh dari hasil sosialisasi nilai religius disepanjang kehidupanya. Dengan demikian, kalau seseorang religius semestinya personalitas dan kepribadianya menggambarkan bangunan integral dari dirinya, yang akan nampak pada wawasan, motivasi, cara berfikir, sikap, perilaku dan tingkat kepuasan pada dirinya yang merupakan hasil dari organisasi sistem psiko-fisiknya. Bentuk religiusitas masyarakat dapat terlihat dari dimensi religiusitas masyarakat yang dikemukakan oleh C.Y Glock dan R. Stark dalam bukunya, American Piety: The mature of Religious Commitment, terdapat lima dimensi dalam religiusitas ${ }^{6}$, yaitu:

a. Religious Belief (The Ideological Dimension) adalah tingkatan sejauh mana seseorang menerima hal-hal yang dogmatik dalam agamanya.

\footnotetext{
${ }^{5}$ Muhaimin, Paradigma Pendidikan Islam: Upaya Mengefektifkan Pendidikan Agama Sekolah, (Bandung: PT. Mahasiswa Rodakarya, 2002), hlm. 287

${ }^{6}$ Febby Indra Firmansyah, Analisis Pengaruh Tingkat Religiusitas Pasien Terhadap Keputusan Menggunakan Jasa Kesehatan (Studi Pada Pasien PKU Muhammadiyah Roemani Semarang), Semarang: Perpustakaan Fakultas Ekonomi Universitas Diponegoro, 2010, hIm. 12-15
} 
Eka: Pengaruh Sikap Religiusitas Terhadap Perilaku Hidup Bersih... | 25 Dimensi keyakinan dalam agama Islam diwujudkan dalam pengakuan (syahadat) yang diwujudkan dengan membaca dua kalimat syahadat, bahwa tidak ada tuhan selain Allah, dan Nabi Muhammad itu utusan Allah.

b. Religious Practice (The Ritual Dimension) yaitu tingkatan sejauh mana seseorang mengerjakan kewajiban-kewajiban ritual dalam agamanya. Wujud dari dimensi ini adalah perilaku masyarakat pengikut agama tertentu dalam menjalankan ritus-ritus yang berkaitan dengan agama. Dimensi praktek dalam agama Islam dapat dilakukan dengan menjalankan ibadah shalat, puasa, zakat, haji ataupun praktek muamalah lainnya ${ }^{7}$.

c. Religious Feeling (The Experiental Dimension) atau bias disebut dimensi pengalaman. Perasaan-perasaan atau pengalaman yang pernah dialami dan dirasakan. Dalam Islam dimensi ini dapat terwujud dalam perasaan dekatatau akrab dengan Allah, perasaan bertawakal (pasrah diri dalam hal yang positif) kepada Allah. Perasaan khusyuk ketika melaksanakan shalat atau berdoa, perasaan tergetar ketika mendengar adzan atau ayat-ayat Al Qur'an, perasaan bersyukur kepada Allah, perasaan mendapat peringatan atau pertolongan dari Allah.

d. Religious Knowledge (The Intellectual Dimension) atau dimensi pengetahuan agama adalah dimensi yang menerangkan seberapa jauh seseorang mengetahui tentang ajaran-ajaran agamanya, terutama yang ada di dalam kitab sucinya. Seseorang yang beragama harus mengetahui hal-hal pokok mengenai dasar-dasar keyakinan, ritusritus, kitab suci dan tradisi dalam agama tersebut ${ }^{8}$.

e. Religious Effect (The Consequential Dimension) yaitu dimensi yang mengukur sejauh mana perilaku seseorang dimotivasi oleh ajaranajaran agamanya dalam kehidupan sosial, misalnya apakah seseorang mengunjungi tetangganya sakit, menolong orang yang kesulitan, mendermawankan hartanya, dan sebagainya ${ }^{9}$.

\footnotetext{
${ }^{7}$ Ibid, hlm. 54

${ }^{8}$ Ibid, hlm. 16

${ }^{9}$ Ibid, hal 18
} 
Perilaku hidup bersih dan sehat (PHBS) adalah semua perilaku yang dilakukan atas kesadaran sehingga anggota keluarga atau keluarga dapat menolong dirinya sendiri dibidang kesehatan dan berperan aktif dalam kegiatan-kegiatan kesehatan di masyarakat ${ }^{10}$. Program PHBS ini merupakan program nasional, yang dibuat untuk seluruh wilayah di Indonesia. Indikator PHBS yang harus diperaktikan dirumah tangga karena dianggap mewakili atau dapat mencerminkan keseluruhan perliku hidup bersih dan sehat, indikator tersebut adalah: Pertolongan persalinan oleh tenaga kesehatan, Bayi di beri ASI ekslusif, Menimbang balita setiap bulan, Ketersediaan air bersih, Ketersediaan jamban sehat, Memberantas jentik nyamuk, Mencuci tangan dengan air bersih dan sabun, Tidak merokok dalam rumah, Melakukan aktifitas fisik setiap hari, Makan buah dan sayur. ${ }^{11}$

Setiap praktik pelaksanaan ibadah dalam agama Islam mengandung manfaat untuk kesehatan baik itu kesehatan fisik dan psikis. Berikut beberapa contoh ibadah dan manfaatnya untuk kesehatan, yaitu:

\section{a. Pelaksanaan Ibadah Shalat}

Posisi Ruku' dengan posisi yang benar akan memberikan manfaat antara lain; menjaga melekatnya tulang tungging dengan tulang belakang sehingga persendian menjadi licin. Bagi wanita, jika tulang tungging melekat dengan tulang belakang, maka mengakibatkan persendian kaku dan tulang pinggul menyempit sehingga sulit melahirkan. Posisi Sujud dengan posisi yang benar akan berpengaruh positif pada tubuh, yaitu: otot menjadi kuat, limpa terpijit sehingga aliran darah menjadi lancar karenanya, berkembangnya otot dada bagi wanita, sehingga menghasilkan buah dada yang bagus bentuknya, sirkulasi darah dari jantung ke seluruh tubuh akan lancar. ${ }^{12}$

\section{b. Manfaat Puasa Bagi Kesehatan}

\footnotetext{
${ }^{10}$ Pusat Promosi Kesehatan RI Bekerjasama dengan TIM Penggerak PKK , Pedoman Pembinaan Perilaku Hidup Bersih dan Sehat (PHBS) di Rumah Tangga melalui Tim Penggerak PKK, Jakarta: Kementrian Kesehatan RI. 2011, hal. 09. http://www.promosikesehatan.com (diakses pada tanggal 15April 2017 pukul 10.00WIB)

${ }^{11}$ Ibid, hal. 10

${ }^{12}$ Deden Suparman, Op.Cit, hlm. 48-70.
} 
Eka: Pengaruh Sikap Religiusitas Terhadap Perilaku Hidup Bersih... | 27

Ibadah puasa memiliki banyak manfaat, diantaranya bagi kesehatan fisik dan psikis, manfaat untuk kesehatan fisik yaitu: mencegah penyakit jantung, penambahan sel darah putih, menghindari penyakit kanker, menghindari penyakit diabetes, mengurangi kecanduan merokok, Sedangkan manfaat bagi kesehatan psikis antara lain: meningkatkan ketakwaan kepada Allah SWT, memupuk kepedulian sosial, meredam marah, meningkatkan kecerdasan. ${ }^{13}$

Penelitian ini adalah penelitian lapangan (field research), dengan dengan pendekatan Metode kombinasi (mixed methods), Model concurrent triangulation (metode campuran kuantitatf dan kualitatif secara berimbang). Populasi dalam penelitian ini adalah seluruh kepala keluarga yang berdomisili di kelurahan dusun curup berjumlah 498 kepala keluarga. Dalam penetapan sampel penulis berpedoman pada pendapat Suharsimi Arikunto yaitu: "apabila subjeknya kurang dari 100 lebih baik diambil semuanya sehingga merupakan penelitian populasi. Selanjutnya jika subjeknya besar dapat diambil antara 10-15\% atau 20-25\% atau lebih"14. Sampel dalam penelitian ini sebanyak $20 \%$ dari 498 kepala keluarga yaitu 100 kepala keluarga yang berdomisili di kelurahan dusun curup. Tehnik pengambilan sampel dilakukan secara acak (random sampling). Teknik pengumpulan data yaitu angket atau kuesioner dan wawancara, serta dokumentasi. Analisis data kualitatif dengan reduksi data, display data, dan conclusion data, serta mengunakan teknik triangulasi sumber dan teknik. Analisis kuantitatif menggunakan program SPSS for Windows Versi 21.

\section{HASIL DAN PEMBAHASAN}

\section{Religiusitas Masyarakat}

Tingkat religiusitas masyarakat kelurahan dusun curup, menurut seluruh perangkat kelurahan dalam kategori sedang, seperti dikatakan salah satu ketua Rt menyatakan "tingkat religiusitas masyarakat sedang,

\footnotetext{
${ }^{13}$ Lelya Hilda Op.Cit, hlm. 53-62

${ }^{14}$ Suharsimi Arikunto, Prosedur Penelitian Suatu Pendekatan Prakek, (Jakarta: Rineka Cipta, 2002), hlm. 108.
} 
28| Fokus: Jurnal Kajian Keislaman dan Kemasyarakatan, Vol.3, No. 01, Juni 2018

karena tidak semua masyarakatnya rajin shalat”. Hasil angket menunjukkan masyarakat dusun curup memiliki sikap religiusitas yang sedang $(57 \%)$. Bentuk religiusitas masyarakat dapat terlihat dari dimensi religiusitas masyarakat yang dikemukakan oleh C.Y Glock dan R. Stark dalam bukunya, American Piety: The mature of Religious Commitment, terdapat lima dimensi dalam religiusitas ${ }^{15}$, yaitu:

\section{a. Religious Belief (The Ideological Dimension)}

Masyarakat kelurahan dusun curup memiliki dimensi keyakinan yang tinggi sekitar 44\%. Hasil wawancara juga menunjukkan masyarakat memiliki dimensi keyakinan yang sangat tinggi, seperti menjalankan perintah Allah dan meningggalkan larangan-Nya, meyakini adanya Malaikat, menjalankan sunah-sunah Rasul, meyakini adanya hari kiamat, dan percaya kepada Qadha dan Qadar. Begitu juga hasil observasi didapati dimensi keyakinan masyarakat kelurahan dusun curup sangat tinggi.

\section{b. Religious Practice (The Ritual Dimension)}

Pelaksanaan dimensi praktek dalam agama Islam masyarakat yaitu $27 \%$ dimensi praktek ibadah tinggi, kategori sedang berjumlah 62\%, dan $11 \%$ kategori rendah. Jadi dapat disimpulkan bahwa masyarakat dusun curup mayoritas memiliki dimensi praktek ibadah yang sedang. Pelaksanaan ibadah shalat fardhu secara full atau lima waktu setiap hari yaitu $23 \%$ masyarakat selalu melaksanakan semua shalat fardhu setiap hari. Hasil tersebut selaras dengan hasil wawancara yaitu "tidak semua masyarakat melaksanakan shalat lima waktu secara penuh". Pelaksanaan Puasa di bulan Ramadhan secara penuh dari analisis hasil angket, yaitu: 24\% masyarakat selalu melaksanakan Puasa di bulan Ramadhan, meski seberat apapun pekerjaan yang dilakukan. Hasil observasi, didapati bahwa kebanyakan masyarakat yang rajin melaksanakan ibadah puasa, tetapi ada juga pada saat bulan Ramadhan, di siang hari tidak melaksanakan puasa, dikarenakan beratnya pekerjaan yang dilakukan, tidak terbiasa sejak kecil, ada penyakit Magh, untuk wanita datangnya menstruasi dll.

\footnotetext{
${ }^{15}$ Febby Indra Firmansyah, Analisis Pengaruh Tingkat Religiusitas Pasien Terhadap Keputusan Menggunakan Jasa Kesehatan (Studi Pada Pasien PKU Muhammadiyah Roemani Semarang), Semarang: Perpustakaan Fakultas Ekonomi Universitas Diponegoro, 2010, hIm. 12-15
} 
Eka: Pengaruh Sikap Religiusitas Terhadap Perilaku Hidup Bersih... | 29

\section{c. Religious Feeling (The Experiental Dimension)}

Masyarakat kelurahan Dusun Curup memiliki pengalaman keagamaan yang sedang (57\%). Secara terperinci pelaksaan dimensi pengalaman yaitu Perasaan bergetar ketika mendengar adzan atau ayatayat Al Qur'an dilantunkan masyarakat kelurahan dusun Curup, yaitu $13 \%$ masyarakat selalu merasa bergetar ketika mendengar adzan atau ayat-ayat Al Qur'an dilantunkan, 17\% menyatakan sering, 36\% jarang, $20 \%$ kadang-kadang merasa bergetar ketika mendengar adzan atau ayatayat Al Qur'an dilantunkan. Perasaan bersyukur atas nikmat Allah Swt dengan rajin ibadah yaitu $23 \%$ masyarakat selalu bersyukur atas nikmat Allah Swt dengan rajin ibadah, Hasil tersebut sedikit berbeda dengan hasil wawancara dengan seluruh perangkat kelurahan dusun Curup, mereka menyatakan masyarakat selalu bersyukur atas nikmat yang diberikan Allah Swt, seperti menurut salah satu ketua Rt yaitu masyarakat selalu bersyukur dengan mengucapkan Alhamdulilah. Selanjutnya menurut ketua Rw. yaitu masyarakat Bersyukur, dengan bersedekah, misalnya: seseorang bersedekah pada malam Jum'at bersyukur apa yang telah diberikan kepada mereka.

\section{d. Religious Knowledge (The Intellectual Dimension)}

Seseorang yang beragama harus mengetahui hal-hal pokok mengenai dasar-dasar keyakinan, ritus-ritus, kitab suci dan tradisi dalam agama tersebut. $41 \%$ anggota masyarakat yang memiliki dimensi pengetahuan keagamaan tinggi, Hasil observasi, didapati masyarakat memahami pentingnya pendidikan seperti banyaknya keluarga yang menyekolahkan anak di madrasah seperti di MIN, dan juga sekolah umum. Selain itu juga mereka memasukkan anak mereka ke TPA untuk mendapatkan ilmu agama. Selain anak-anak, bapaknya juga rajin mengikuti Majelis Ta'lim dan mendirikan pengajian di daerah masingmasing, untuk menambah ilmu keagamaannya.

\section{e. Religious Effect (The Consequential Dimension)}

Masyarakat dusun curup memiliki dimensi konsekuensi beragama yang sedang (61\%). Secara terperinci dimensi konsekuensi beragama dapat dilihat dari indikatornya, yaitu: Kebiasaan mengunjungi dan merawat tetangga yang sedang dalam keadaan sakit masyarakat kelurahan dusun curup, yaitu $8 \%$ masyarakat selalu mengunjungi dan merawat 
30| Fokus: Jurnal Kajian Keislaman dan Kemasyarakatan, Vol.3, No. 01, Juni 2018

tetangga yang sedang dalam keadaan sakit. Hasil observasi didapati bahwa ketika ada tetangga yang sakit, maka tetangga sekitar akan membesuknya, dengan membawa sedikit oleh-oleh, namun yang merawat dan menunggui di rumah sakit atau di rumah ialah keluarga dekat tetangga yang sakit tersebut, namun ketika ada yang meninggal dunia, masyarakat aktif dalam mengurus mayat tetangganya tersebut sampai pada proses penguburan dan pelaksanaan yasinan dan tahlilan.

Sikap tolong-menolong yang dimiliki masyarakat kelurahan dusun curup, yaitu $19 \%$ masyarakat selalu membantu seseorang jika memerlukan bantuan dengan ikhlas. Hasil analisis tersebut selaras dengan hasil wawancara dengan seluruh perangkat kelurahan dusun curup, mereka mengatakan ada tetangga yang cuek atau tidak peduli dan ada juga tetangga yang memberikan bantuan seperti meminjamkan mobil untuk membawa tetangga yang sakit dan memberikan bantuan pinjaman uang, kemudian saling berbagi makanan ketika bulan Ramadhan.

\section{Perilaku Hidup Bersih dan Sehat (PHBS) Masyarakat Dusun Curup}

Menurut salah satu ketua Rt PHBS adalah cara hidup yang baik, dan agar selalu tetap sehat. Tingkat perilaku hidup bersih dan sehat (PHBS) tinggi sebesar 24\%, 56\% masyarakat kategori sedang, dan 20\% kategori rendah. Jadi dapat disimpulkan bahwa masyarakat Kelurahan Dusun Curup memiliki perilaku hidup bersih dan sehat (PHBS) yang sedang. Perilaku Hidup Bersih dan Sehat (PHBS) masyarakat kelurahan dusun Curup dapat digambarkan dengan menganalisis indikatornya yaitu:

\section{a. Pertolongan persalinan oleh tenaga kesehatan}

Tingkat penggunaan tenaga kesehatan ketika melahirkan masyarakat kelurahan dusun Curup. tergolong tinggi (52\%) dalam penggunaan pertolongan tenaga kesehatan seperti dokter dan bidan yang memiliki izin ketika melahirkan.

\section{b. Pemberian ASI Ekslusif pada Bayi}

Pemberikan ASI Ekslusif kepada bayinya sejak dilahirkan sampai usia 6 bulan pada masyarakat kelurahan dusun curup sudah dalam kategori tinggi (46\%). Sebagian masyarakat melanjutkan pemberian ASI kepada bayinya sampai usia 2 tahun, karena pemberian ASI eksklusif 
membawa banyak manfaat untuk perekonomian keluarga, dan sebagai KB alami untuk para ibu, tetapi ada beberapa ibu yang tidak melanjutkan pemberian ASI kepada bayinya, dikarenakan, Air ASI yang dimiliki ibu sudah tidak keluar lagi, sehingga tidak dapat memberikan ASI Ekslusif di usia 0-6 bulan, bahkan sampai 2 tahun.

\section{c. Menimbang balita setiap bulan}

Kepatuhan masyarakat kelurahan dusun curup dalam menimbang balitanya secara rutin sudah tergolong tinggi (46\%). Menimbang balita secara rutin membawa manfaat dalam mengontrol dan menjaga kesehatan balita. Hasil analisis tersebut selaras dengan hasil wawancara bahwa masyarakat menimbang balita setiap bulan, ketika ada kegiatan posyandu di rumah warga dan di kantor lurah dari tim kesehatan.

\section{d. Ketersediaan dan Penggunaan Air Bersih}

Tingkat penggunaan air bersih masyarakat dusun curup, kategori sedang. Hasil analisis tersebut selaras dengan hasil wawancara bahwa masyarakat menggunakan air bersih, seperti air sumur dan air PDAM. Sementara hasil observasi didapati bahwa kelurahan dusun Curup sudah dilengkapi dengan fasilitas air PDAM, namun, terkadang air PDAM sering mati/tidak hidup, sehingga menyebabkan, masyarakat menggunakan air selokan dan mata air di daerah persawahan yang ada dilingkungannya. Hasil observasi menunjukkan masih ada masyarakat yang mengunakan air yang kurang bersih seperti air selokan untuk keperluan mencuci perlengkapan makan dan pakain, seperti piring dan baju, dll. Tidak hanya itu, keperluan mencuci makanan juga dilakukan dengan air selokan seperti mencuci sayuran, ikan dan ayam. Sementara, aliran air selokan belum diketahui kebersihannya, karena sampah juga ikut mengalir di atas aliran air selokan tersebut. Tidak hanya itu, penelti pernah melihat, bahwa ada kandang sapi yang juga terletak di pangkal aliran selokan, yang mana kotoran sapi tersebut ikut mencemari kebersihan air selokan.

\section{e. Ketersediaan dan Penggunaan Jamban Sehat}

Tingkat penggunaan jamban sehat masyarakat kelurahan dusun curup dalam kategori sedang (65\%), hasil wawancara juga menyatakan, penggunaan jamban bersih dan sehat masyarakat kelurahan dusun curup sudah baik. Sementara hasil observasi menunjukkan bahwa ada beberapa 
32| Fokus: Jurnal Kajian Keislaman dan Kemasyarakatan, Vol.3, No. 01, Juni 2018

masyarakat yang masih menggunakan jamban kurang sehat, dengan menggunakan tempat sepi dan aliran air selokan sebagai tempat membuang air besar dan kecil.

\section{f. Memberantas Jentik Nyamuk}

Tingkat kepedulian masyarakat dalam memberantas jentik nyamuk dalam kategori sedang (50\%). Hasil wawancara juga menyatakan, tingkat kepedulian masyarakat dusun curup dalam memberantas jentik nyamuk seperti kegiatan 3M (menguras, menutup dan mengubur) dan penyemprotan (flogging). Sementara hasil observasi menunjukkan bahwa kegiatan penyemprotan belum terlihat dilakukan. Adanya tumbukan sampah di beberapa tempat juga akan memicu berkembangnya nyamuk.

\section{g. Mencuci Tangan dengan Air Bersih dan Sabun}

Tingkat kebiasaan mencuci tangan dengan air bersih dan sabun dalam kategori sedang (57\%). Hasil wawancara menyatakan, bahwa perangkat kelurahan kurang mengetahui tingkat kebiasaan mencuci tangan dengan air bersih dan sabun, tetapi mereka menerapkan dikeluarganya masing-masing. Kebiasaan mencuci tangan dilakukan saat sebelum makan dan sesudah makan. Hasil observasi menunjukkan, kebiasaan membersihkan tangan ketika makan dengan air masih terlihat ketika ada acara di rumah warga, tuan rumah masih menyiapkan mangkok disertai air untuk membersihkan tangan tamu sebelum dan sesudah makan.

\section{h. Tidak Merokok dalam Rumah}

Tingkat kepatuhan masyarakat dusun curup terhadap larangan merokok meminum minuman keras di dalam rumah dalam kategori sedang $(35 \%)$. hasil wawancara juga menyatakan, kebiasaan merokok masyarakat di rumah, dilakukan apabila ngobrol dengan tamu yang datang. Sementara hasil observasi menunjukkan bahwa kebiasaan merokok sudah merata dilakukan oleh bapak-bapak, tidak hanya bapakbapak, bahkan para pemuda yang masih sekolah dan belum memiliki pekerjaan juga sudah merokok. Sementara minum-minuman keras, biasanya dilakukan jika ada warga yang menggelar hajatan dan disertai musik yang keras. 


\section{i. Melakukan aktifitas fisik setiap hari}

Tingkat aktifitas fisik masyarakat dusun curup dalam kategori sedang (65\%). Hasil wawancara juga menyatakan, masyarakat ada yang sering beraktifitas, ada juga yang tidak. Aktifitas fisik yang dilakukan seperti lari pagi, maroton, ataupun pergi beraktifitas ke kebun. Sementara hasil observasi menunjukkan kegiatan olahraga bersama terlihat belum banyak dilakukan, hanya ada beberapa warga yang aktif ikut berolahraga dengan ikut senam bersama di lapangan Setia Negara pada hari Mingu pagi.

\section{j. Makan Buah dan Sayur}

Tingkat konsumsi buah dan sayur masyarakat dusun curup dalam kategori sedang (64\%). Hasil wawancara juga menyatakan, masyarakat memiliki memiliki tingkat ekonomi yang beragam, bagi yang ekonominya mapan mereka akan mengkonsumsi makan 4 sehat 5 sempurna, baik sayurnya, buahnya dan dagingnya, tetapi bagi masyarakat yang ekonominya lemah, mereka sering makan sayur atau buah saja, tidak secara lengkap. Sementara hasil observasi masyarakat lebih memfokuskan penghasilan sayur dan buah yang ada untuk dijual, untuk menghasilkan uang yang gunanya memenuhi kebutuhan yang lain.

\section{Pengaruh Sikap Religiusitas terhadap Perilaku Hidup Bersih dan Sehat (PHBS) Masyarakat Dusun Curup}

Berdasarkan hasil Out Put Uji Regresi diketahui bahwa konstanta $(\alpha)=6,872$ koefisien regresi $(b)=\mathbf{0 . 8 9 5}$. Konstanta dan koefisien regresi tersebut dapat digunakan untuk membuat persamaan regresi estimasi. Persamaan regresi estimasi yang diperoleh dari penghitungan tersebut adalah: $\mathrm{Y}=6,872+\mathbf{0 . 8 9 5} \mathrm{X}$. Sikap religiusitas memiliki pengaruh kontribusi sebesar 83,80\% terhadap PHBS masyarakat kelurahan dusun curup dan sisanya dipengaruhi oleh faktor-faktor lain diluar sikap religiusitas. Peningkatan sikap religiusitas akan diikuti dengan peningkatan PHBS, atau penurunan sikap religiusitas akan diikuti dengan penurunan PHBS.

Hasil analisis angket tersebut, berbeda dengan hasil wawancara dengan salah satu Rt bahwa pengaruh sikap religiusitas terhadap PHBS masyarakat dalam kategori kurang, contonya: sampah masih berserakan 
34| Fokus: Jurnal Kajian Keislaman dan Kemasyarakatan, Vol.3, No. 01, Juni 2018

dijalan-jalan, selokan, sungai, dan air comberan yang tergenang. Sementara menurut ketua Rt. lainnya memiliki pengaruh, seperti; masyarakat yang sering shalat, beribadah tentu pakaiannya harus bersih dan rapi jadi mereka berasumsi bahwa lingkungan indah ketika mereka melaksanakan shalat juga rapi. Sementara menurut ketua Rt. lainnya memiliki pengaruh, seperti; masyarakat yang sering shalat, beribadah tentu pakaiannya harus bersih dan rapi jadi mereka berasumsi bahwa lingkungan indah mereka ketika melaksanakan shalat juga rapi. Jadi ada kaitannya di dalam hadits nabi dikatakan: kebersihan itu sebagian dari iman, kemudian masyarakat yang memiliki religiusitas tinggi akan membuang sampah pada tempatnya dan memasukan sampah di dalam karung sebelum di buang.

Berikut ini akan dibahas lebih lanjut pengaruh sikap religiusitas terhadap PHBS masyarakat dusun Curup

\section{a. Pengaruh Sikap Religiusitas terhadap Perilaku Hidup Bersih Masyarakat Dusun Curup}

Hasil penelitian di atas menunjukkan bagaimana pelaksaan dimensi ritual terkhusus pada ibadah shalat masyarakat dusun curup yaitu ada $23 \%$ masyarakat selalu melaksanakan semua shalat fardhu setiap hari, dan sisanya mengerjakan shalat, tapi tidak secara full lima waktu sehari. Pelaksaan sikap religius pada dimensi ritual seperti shalat membawa pengaruh $42 \%$ terhadap penggunaan air bersih dalam kehidupan seharihari, seperti perilaku masyarakat dusun curup yang mencuci tangan dengan air bersih dan sabun, dan selalu menggunakan jamban bersih dan sehat. Kemudian dimensi konsekuensi bergama masyarakat dusun curup seperti sikap menjaga kebersihan lingkungan sebagai bukti keimanan membawa pengaruh kepada kepedulian masyarakat dusun curup dalam memberantas jentik nyamuk dalam sebesar 50\%. Hasil wawancara juga menyatakan, tingkat kepedulian masyarakat dusun curup dalam memberantas jentik nyamuk seperti kegiatan 3M (menguras, menutup dan mengubur) dan penyemprotan (flogging).

\section{b. Pengaruh Sikap Religiusitas terhadap Perilaku Hidup Sehat Masyarakat Dusun Curup}

Setiap praktik pelaksanaan ibadah dalam agama Islam mengandung manfaat untuk kesehatan baik itu kesehatan fisik dan psikis. Namun, 
dalam penelitian ini akan dianalisis pengaruh sikap religiusitas terhadap kesehatan masyarakat berdasarkan pada manfaat ibadah secara psikis, karena dapat terlihat dari perilaku yang ditampilkan masyarakat. Untuk pengaruh secara medis, peneliti tidak melakukan lebih lanjut, karena merasa bukan bidang ahlinya.

\section{c. Pengaruh terhadap Kesehatan Psikis/Mental Masyarakat}

Beberapa manfaat shalat yang dikaitkan dengan kesehatan Psikis manusia, yaitu; ${ }^{16}$

a) Mendidik manusia agar taat kepada pimpinan yang memberi komando, Hal ini sejalan dengan hasil penelitian bahwa ada $13 \%$ masyarakat selalu bergetar ketika mendengar adzan atau ayatayat Al Qur'an dilantunkan, dibuktikan ketika dikumandangkan adzan, yang bergetar hatinya akan langsung ke mushollah atau masjid untuk melaksanakan shalat.

b) Mendidik manusia agar memiliki kedislipinan yang tinggi dalam melaksanakan tugas yang dipikulkan kepadanya. Hasil penelitian menunjukkan masyarakat memiliki kepatuhan yang tinggi dalam menggunakan pertolongan tenaga kesehatan seperti dokter dan bidan yang memiliki izin ketika melahirkan, pemberian ASI Ekslusif kepada bayinya sejak dilahirkan sampai usia 6 bulan. Kemudian melanjutkan pemberian ASI kepada bayinya sampai usia 2 tahun. Kepatuhan menimbang Balitanya secara rutin.

c) Mendidik manusia untuk memiliki sikap optimis dalam menyongsong masa depan. Hasil penelitian menunjukkan tingkat kepedulian masyarakat dusun curup dalam memberantas jentik nyamuk dalam kategori sedang (50\%). tingkat kepedulian masyarakat dusun curup dalam memberantas jentik nyamuk seperti kegiatan 3M (menguras, menutup dan mengubur) dan penyemprotan (flogging). Hal ini mengindikasikan masyarakat peduli dalam menyongsong masa depan yang bebas dari penyakit demam berdarah.

${ }^{16}$ Deden Suparman, Pembelajaran Ibadah Shalat dalam Perpektif Psikis dan Medis, Jurnal Edisi Juli 2015 Volume IX No. 2, ISSN 1979-8911, hal. 48-70 
36| Fokus: Jurnal Kajian Keislaman dan Kemasyarakatan, Vol.3, No. 01, Juni 2018

d) Menentramkan jiwa, karena dengan shalat seseorang akan merasa senantiasa dekat dengan Allah SWT. Hasil penelitian bahwa $14 \%$ masyarakat kelurahan dusun curup yang selalu berzikir mengingat Allah setiap hari nya ketika selesai shalat. Berzikir mengingat Allah sering dilakukan pada malam jum'at, seperti membaca surah Yasin disertai zikir dan tahlil untuk dikirim kepada arwah keluarga yang sudah meninggal. Pada malam minggu juga rutin dilakukan pengajian bapak-bapak yang mana di dalamnya juga membaca surah Yasin, zikir dan tahlil.

e) Mendorong manusia berani menghadapi problematika kehidupan dengan hati sabar dan tabah. Hasil penelitian menunjukkan $20 \%$ masyarakat selalu bertambah keimanannya setelah mengalami kesulitan. Masyarakat bersyukur dengan mengucapkan Al-hamdu lillahi rabbil 'alamin ketika mendapat cobaan atau mendapat musibah mengucapkan Inna lillahi wa inna ilaihi rajiun.

f) Mendidik manusia agar bersikap sportif dan gentleman untuk mengakui kesalahan dan dosanya. Hasil penelitian menunjukkan 23\% masyarakat selalu bersyukur atas nikmat Allah Swt dengan rajin ibadah. Kemudian masyarakat selalu bersyukur dengan mengucapkan Alhamdulilah dan dengan bersedekah, misalnya: seseorang bersedekah pada malam Jum'at bersyukur apa yang telah diberikan kepada mereka.

g) Menghindarkan manusia dari berbuat keji dan munkar (jahat). Hasil penelitian menunjukkan ada beberapa masyarakat yang tidak peduli, dan ada yang peduli seperti masyarakat saling menjaga keamanan dan ketertiban lingkungan dengan melaksanakan siskambling dan mendirikan pengajian bapakbapak setiap malam jum'at dan malam minggu, sementara ibuibu saling mengenal dengan acara arisan setiap bulan yang juga diisi dengan berbagai kegiatan yang bermanfaat.

Sedangkan manfaat ibadah puasa untuk kesehatan psikis/mental antara lain: ${ }^{17}$

${ }^{17}$ Lelya Hilda , Puasa dalam Kajian Islam dan Kesehata, Jurnal Hikmah, Vol. VIII, No. 01 Januari 2014, 53-62 
Eka: Pengaruh Sikap Religiusitas Terhadap Perilaku Hidup Bersih... | 37

a) Meningkatkan ketakwaan kepada Allah SWT. Hasil penelitian menunjukkan masyarakat kelurahan dusun curup memiliki dimensi keyakinan yang tinggi sekitar $44 \%$. Hasil wawancara juga menunjukkan masyarakat memiliki dimensi keyakinan yang sangat tinggi, seperti menjalankan perintah Allah dan meningggalkan larangan-Nya, meyakini adanya Malaikat, menjalankan sunah-sunah Rasul, meyakini adanya hari kiamat, dan percaya kepada Qadha dan Qadar. Begitu juga hasil observasi didapati dimensi keyakinan masyarakat kelurahan dusun curup sangat tinggi.

b) Memupuk kepedulian sosial, hasil penelitian ada $19 \%$ masyarakat selalu membantu seseorang jika memerlukan bantuan dengan ikhlas, tetapi ada juga tetangga yang cuek atau tidak peduli. Bantuan yang diberikan tetangga seperti meminjamkan mobil untuk membawa tetangga yang sakit dan memberikan bantuan pinjaman uang, kemudian saling berbagi makanan ketika bulan Ramadhan.

c) Meredam marah, hasil penelitian menunjukkan 13\% masyarakat selalu memaafakan orang-orang yang telah menyakiti hati, $7 \%$ menyatakan sering, 32\% menyatakan jarang, 37\% menyatakan kadang-kadang. $11 \%$ menyatakan tidak pernah memaafakan orang-orang yang telah menyakiti hati secara dalam.

d) Meningkatkan kecerdasan. Hasil penelitian menunjukkan masyarakat dusun curup mayoritas memiliki pengetahuan keagamaan yang tinggi. Hal ini didukung dengan adanya sekolah umum, dan Madrasah serta STAIN Curup di kelurahan dusun curup. Kaum bapak-bapak antusias dalam menambah pengetahuan agama seperti mendirikan pengajian di daerah masing-masing yang diisi dengan membaca Yasin, Zikir, dan Do'a, serta ada ceramah agama Islam. Untuk kaum ibu-ibu mengikuti Majelis Ta'lim yang diisi dengan kegiatan mengaji, rebana dan ceramah agama Islam.

\section{d. Pengaruh terhadap Kesehatan Fisik}

Ibadah puasa memiliki banyak manfaat, diantaranya bagi kesehatan fisik dan psikis, manfaat untuk kesehatan fisik yaitu: mencegah penyakit 
jantung, penambahan sel darah putih, menghindari penyakit kanker, menghindari penyakit diabetes, mengurangi kecanduan merokok dan alkohol. $^{18}$

Hasil penelitian menunjukkan tingkat kepatuhan masyarakat dusun curup terhadap larangan merokok meminum minuman keras di dalam rumah dalam kategori sedang (35\%). hasil wawancara juga menyatakan, kebiasaan merokok masyarakat di rumah, dilakukan apabila ngobrol dengan tamu yang datang. Sementara hasil observasi menunjukkan bahwa kebiasaan merokok sudah merata dilakukan oleh bapak-bapak, tidak hanya bapak-bapak, bahkan para pemuda yang masih sekolah dan belum memiliki pekerjaan juga sudah merokok. Sementara minum-minuman keras, biasanya dilakukan jika ada warga yang menggelar hajatan dan disertai musik yang keras.Aktifitas fisik masyarakat setiap hari, terlihat belum banyak dilakukan, kegiatan senam bersama dilakukan hanya di STAIN Curup untuk kalangan mahasiswa dan pegawai. Sementara ada beberapa warga yang aktif ikut berolahraga dengan ikut senam bersama di lapangan Setia Negara pada hari Mingu pagi.

Tingkat aktifitas fisik masyarakat dusun curup dalam kategori sedang (65\%). Hasil wawancara juga menyatakan, masyarakat ada yang sering beraktifitas, ada juga yang tidak. Aktifitas fisik yang dilakukan seperti lari pagi, maroton, ataupun pergi beraktifitas ke kebun. Sementara hasil observasi menunjukkan kegiatan olahraga bersama terlihat belum banyak dilakukan, hanya ada beberapa warga yang aktif ikut berolahraga dengan ikut senam bersama di lapangan Setia Negara pada hari Mingu pagi.

\section{PENUTUP}

Sikap religiusitas memiliki pengaruh kontribusi sebesar 83,80\% terhadap PHBS masyarakat dusun curup. Sikap religiusitas masyarakat memiliki pengaruh terhadap perilaku bersih masyarakat, seperti dimensi ritual beragama membawa pengaruh terhadap perilaku penggunaan air bersih dalam kehidupan sehari-hari. Kemudian dimensi konsekuensi beragama masyarakat membawa pengaruh terhadap perilaku masyarakat

\footnotetext{
${ }^{18}$ Ibid, hlm. 53-62
} 
Eka: Pengaruh Sikap Religiusitas Terhadap Perilaku Hidup Bersih... | 39 dalam memberantas jentik nyamuk. Pengaruh sikap religiusitas terhadap kesehatan Psikis/Mental masyarakat.

\section{DAFTAR PUSTAKA}

Abd. Rahman, Molid. Muliiden, Kebersihan Alam Sekitar Mengikut Perspektif Islam, Jurnal Usuluddin.

Ahmadi, Abu dkk. Psikologi Sosial. Jakarta: Rineka Cipta. Cet. 2. 1999.

Aly, Hery Noer dan Munzier Suparta. Watak Pendidikan Islam, Jakarta; Friska Agung Insani. 2000.

Arikunto, Suharsimi. Prosedur Penelitian. Jakarta:Rineka Cipta. 2002

Creswell, Jhon W. Research Design (Pendekatan kualitatif, kuantitatif dan mixed) Yogyakarta; Pustaka Pelajar. 2012.

Darajat, Zakiah. Doa Menunjang Semangat Hidup. Jakarta: Ruhana. 1996.

Departemen Pendidikan Nasional. Kamus Besar Bahasa Pusat Indonesia, PT. Gramedia Pustaka Utama: Jakarta. 2008.

Dinas Kesehatan Provinsi Bengkulu. Profil Kesehatan Provinsi Bengkulu Tahun 2014. Bengkulu. 2015

Gani, Husni Abdul. 2013. Perilaku Hidup Bersih dan Sehat (PHBS) pada Masyarakat Using di Kabupaten Banyuwangi. Jurnal IKESMA Volume 9 Nomor 2 September 2013.

Giska. Analisis Regresi Dengan Spss 17 dan Cara Membacanya. 2017. http://giskapuas.blogspot.co.id/2012/01/analisis-regresi-denganspss-17-dan.html, di akses tgl 3-11-2017.

Indra, Febby Firmansyah. 2010. Analisis Pengaruh Tingkat Religiusitas Pasien Terhadap Keputusan Menggunakan Jasa Kesehatan (Studi Pada Pasien PKU Muhammadiyah Roemani Semarang), Semarang: Perpustakaan Fakultas Ekonomi Universitas Diponegoro.

Hilda, Lelya. Puasa dalam Kajian Islam dan Kesehatan, Jurnal Hikmah, Vol. VIII, No. 01 Januari 2014.

Jalaluddin. Psikologi Agama. Jakarta; Raja Grafindo Persada. 2005. 
40| Fokus: Jurnal Kajian Keislaman dan Kemasyarakatan, Vol.3, No. 01, Juni 2018

Kemenkes, RI.. Peraturan Menteri Kesehatan Republik Indonesia nomor : 2269/MENKES/PER/XI/2011 - Pedoman Pembinaan Perilaku Hidup Bersih dan Sehat (PHBS). Jakarta: Kementrian Kesehatan RI. http://www.promosikesehatan.com (Diakses pada tanggal 15 April 2017 pukul 10.00 WIB ). 2011.

Muhaimin. Paradigma Pendidikan Islam: Upaya Mengefektifkan Pendidikan Agama Sekolah. Bandung; Mahasiswa Rodakarya. 2002.

Nashori, Fuad dan Diana Mucharam. Mengembangkan Kreatifitas dalam Psikologi Islam, Yogyakarta; Menara Kudus. 2002.

Pusat Promosi Kesehatan RI Bekerjasama dengan TIM Penggerak PKK, Pedoman Pembinaan Perilaku Hidup Bersih dan Sehat (PHBS) di Rumah Tangga melalui Tim Penggerak PKK, Jakarta: Kementrian Kesehatan RI. 2011. Dalam http://www.promosikesehatan.com (diakses pada tanggal 15April 2017 pukul 10.00WIB)

Rakhmat, Jalaluddin, Psikologi Islam. Jakarta: Raja Grafindo. 1966.

Reza, Fani Iredho. 2013. Hubungan antara Religiusitas dengan Moralitas pada Remaja di Madrasah Aliyah (MA). Jurnal Humanitas, Vol. X No.2 Agustus 2013.

Sugiyono. Metode Penelitian Kombinasi (Mixed Methods). Alfabeta: Bandung. 2014.

Suparman, Deden. Pembelajaran Ibadah Shalat dalam Perpektif Psikis dan Medis, Jurnal Edisi Juli 2015 Volume IX No. 2, ISSN 19798911.

Yayasan Penyelenggara Penterjemah Al-Qur'an. Al Qur'an dan Terjemahnya. Bandung; Sinar Baru Algensindo Offset. 2010.

Wikipedia.https://id.wikipedia.org/wiki/Dusun_Curup,_Curup_Utara,_Re jang_Lebong, diakses tanggal 15 April 2017 